\title{
Seasonal calendar by the Sama-Bajau people: Focusing on the wind calendar in Banggai Islands
}

\author{
Makibi Nakano ${ }^{1 *}$ \\ ${ }^{1}$ Graduate School of Asian and African Area Studies, Kyoto University, 46 Yoshidashimoadachicho, \\ Sakyo Ward, Kyoto 606-8304, Japan
}

\begin{abstract}
In local societies, people utilize indigenous ecological knowledge to engage in their livelihood. The study draws from a comparison of the indigenous calendars based on seasonal winds used by the Sama-Bajau fishermen in Banggai Islands, Central Sulawesi, Indonesia. In previous studies about Sama-Bajau people, their ecological background of fishing activity was overlooked, and their seasonal calendar in coral reef area was only reported. This study conducted a qualitative research through semi-structured interviews and participant observation in four settlements. Based on a comparison between the main and other settlements, the study analyzed their indigenous ecological calendar using scientific data and comparing with other society's data. The results revealed that the classifications of each calendar are critically different. Therefore, according to interviewees, they cannot determine if they previously resided in a region. The findings also suggested that they recognize seasons with a punctual and an irregular classification. Today, they face a contradiction between the indigenous seasonal and modern calendars. Given this problem, a relationship of antagonism and harmony with seasonal knowledge and modern knowledge is observed. A discussion of their adaptation process regarding the diachronic maritime ecology is provided.
\end{abstract}

\section{Introduction}

Indigenous people utilize ecological knowledge in their livelihood using appropriate time and space. In particular, the author reported that the Sama-Bajau fishermen in Indonesia have adapted ecological cognition and knowledge to identify appropriate fishing spots. The author revealed that fishermen classified sea space based on submarine topography, thus

* Corresponding author: maknaknet1@me.com 
acquiring a 'spot-based understanding.' In other words, this understanding is a component of the spatial aspect of fishermen's ecological cognition [10]. Describing one aspect is insufficient for understanding their culture. Thus, previous studies shed light on the temporal aspect, and only fishermen in coral reef area.

Before the Gregorian calendar, the natural calendar was utilized. Basic ethnographic studies on indigenous calendars have been conducted worldwide. In Indonesia, for example, a Sundanese village in West Java used a traditional calendar for agricultural operations based on seasonality and the stars [5]. People from Sumba island utilized an astronomical operation to determine the appropriate periods for rituals, which was shared by transmission of information from a settlement to another one. However, research topics follow a certain tendency. Except for a few reports, previous research mostly focused on farmers or rituals and mainly discussed the relationship between agriculture and natural phenomenon. In coastal areas, fishermen also generally recognize the ecological environment according to their culture and devise a seasonal calendar for fishing. Nevertheless, studies on the indigenous knowledge of natural calendars utilized by fishermen are lacking. Investigating the seasonal calendars utilized by fishermen can provide insight on the knowledge considered appropriate by local residents from local settlements and the ecological cognition underlying the creation of these calendars.

Another trend in the literature is the lack of research on the Sama-Bajau people, who are known as 'sea nomads' and 'sea gypsy' because of their lifestyle of living in boats. This group of people has moved to the land and is scattered across Malaysia, Philippines, and Indonesia. The majority of research has been conducted on surrounding Sulu islands or settlements built on or around coral reefs. The fishing activities and environmental cognition in these communities are deemed representative examples of the indigenous people. However, a few of them have moved inland, whereas others have built artificial islands. Thus, the current study conducts on-site fieldwork in blank areas, namely the areas where there is no prominent coral reef are, such as the Banggai Islands in Central Sulawesi, in contrast to previous research sites.

The third problem is the deviation from academic discipline. The research on the SamaBajau started from its history of origin to the migration of the scattered groups [14][11] and linguistic classification [13][3]. In the previous years, research shifted to the creation and restructuring of identity by investigating the relationships. For example, Sama-Bajau people between nations or religions [1], mobility, and maritime networks [9]. For example, Nagatsu [8] proposed that 'although previous research emphasized that the Sama people are full-time fishermen and closely connected to the maritime environment, previous studies have not taken good care of maritime activities and environmental recognition in the background.'

This study aims to compare the indigenous calendars based on seasonal winds and devised by the Sama-Bajau people, particularly fishermen, in Banggai Islands, Central Sulawesi, Indonesia. The remainder of the paper is structured as follows. Section 2 provides the methods and bries information about research sites. Section 3 provides a comparison of the indigenous calendars according to seasonal winds in the three other settlements of the same area. Based on concrete data from a qualitative interview. Next, it discusses how the Sama-Bajau fishermen recognized and classified the seasons and how modernization influenced the calendars. Section 4 concludes the study.

\section{Method}

The author conducted fieldwork and document investigation. Semi-structured interviews and participant observation were conducted intermittently from 2016 to 2020 mainly in village K, Peling Island in the province of Central Sulawesi, Indonesia. Interviews were 
conducted mainly in Indonesian, and a retired fisherman assisted the author in the interpretation of the Sama-Bajau language. A total of 15 fishermen, who were recommended and introduced by retired fishermen and known as those with ample knowledge about the sea, were interviewed. Interviews with three out of the total number of interviewees; fisherman A, B, and C, and retired fishermen; fisherman D were further carried out to obtain in-depth information about fishing knowledge.

Fisherman A engages into hand-line fishing and that with fake bites, and sometimes also engages into long-line fishing for general fish. Both methods were conducted by him alone. He was born in village $\mathrm{K}$ in 1958 . He is a fisherman friend with fisherman $\mathrm{D}$, both of them are particularly known well as 'smart fisherman (nelayan pintar)' by villagers. He has no experience to stay for long term in other settlements although sometimes takes a rest in other settlements.

Fisherman B engages into hand-line fishing and that with fake bites, conducted by him alone. He was born in village $\mathrm{K}$ in 1960 . He has no experience to stay for long term in other settlements although sometimes takes a rest in other settlements.

Fisherman $\mathrm{C}$ engages into skin diving, sometimes hand-line fishing and that with fake bites. Usually he goes fishing with his friends, or his relatives (keluarga). He goes with them and after arriving at fishing spots, they engage fishing separatory. He was born in village $\mathrm{K}$ in 1972 . He has no experience to stay for long term in other settlements although sometimes takes a rest in other settlements.

Fisherman D is a retired fisherman. Before his retirement, he had engaged into handline fishing and that with fake bites, and sometimes also engages into long-line fishing for general fish and sharks. Usually he goes fishing with fisherman A and especially utilize long-line fishing. His parents are Mandar, he was born in Kendari city in Southeast Sulawesi. He had engaged into sailor, and sometimes stay for a short time in village K. Although he was not Sama-Bajau originally, however, after marrying with a woman of Same-Bajau in village K, he became Sama-Bajau. He moved to village K in 1971, engaged into fishing with fisherman A until his wife died.

Village $\mathrm{K}$ is the settlement with the biggest population among the Sama-Bajau people in Banggai Islands. According to the village office, the population of village $\mathrm{K}$ is made up of 3,793 residents and 1,010 households as of 2017. The main inhabitants of the village are the Sama-Bajau and Mandar, Bugis, Makassar, and Chinese.

Table 1 shows the average monthly precipitation in the Banggai prefecture from 2009 to 2013, whereas Table 2 shows the temperature and humidity values in the Banggai Kepulauan Regency as of 2015. Figure 1 depicts a hythergraph of the Banggai Kepulauan Regency for 2015. In Table 1 and Figure 1, data in May are considered erroneous because data in other months usually indicate high precipitation, such as April and June. According to the data, the rainy season spans roughly from December to July, whereas the dry season starts in August and ends in November. Throughout the year, the average temperature ranges from $25^{\circ} \mathrm{C}$ to $30^{\circ} \mathrm{C}$.

Table 1. Precipitation and Rainy Days in Banggai Kepulauan Regency for 2015 [16] 


\begin{tabular}{ccc}
\hline & Precipitation $\left(\mathrm{mm}^{3}\right)$ & Rainy Days \\
\hline January & 119,80 & 12 \\
February & 61,50 & 11 \\
March & 57,60 & 22 \\
April & 165,00 & 20 \\
May & 26,70 & 17 \\
June & 177,00 & 23 \\
July & 139,00 & 20 \\
August & 23,00 & 14 \\
September & 3,00 & 5 \\
October & 0,00 & 5 \\
November & 33,00 & 4 \\
December & 93,00 & 19
\end{tabular}

Table 2. Temperature and Humidity in Banggai Kepulauan Regency for 2015 [16]

\begin{tabular}{ccccccc}
\hline & \multicolumn{2}{c}{ Temeparture $\left({ }^{\circ} \mathrm{C}\right)$} & \multicolumn{4}{c}{ Humidity $(\%)$} \\
& Max & Min & Avarage & Max & Min & Avarage \\
\hline January & 32,30 & 24,90 & 29,00 & 96,00 & 42,00 & 76,00 \\
February & 32,30 & 25,60 & 29,00 & 97,00 & 54,00 & 76,00 \\
March & 31,40 & 25,00 & 28,20 & 95,00 & 59,00 & 76,00 \\
April & 31,70 & 25,00 & 28,20 & 94,00 & 59,00 & 75,00 \\
May & 30,70 & 24,60 & 27,70 & 95,00 & 59,00 & 75,00 \\
June & 29,80 & 24,20 & 26,90 & 95,00 & 62,00 & 78,00 \\
July & 29,70 & 24,20 & 26,60 & 96,00 & 60,00 & 72,00 \\
August & 29,10 & 23,30 & 26,20 & 91,00 & 58,00 & 70,00 \\
September & 30,20 & 23,90 & 27,20 & 85,00 & 31,00 & 65,00 \\
October & 30,90 & 24,30 & 28,10 & 90,00 & 49,00 & 67,00 \\
November & 32,20 & 25,70 & 29,70 & 93,00 & 56,00 & 70,00 \\
December & 32,70 & 25,60 & 29,80 & 80,00 & 67,00 & 73,00
\end{tabular}


Hythergraph of Banggai Kepulauan Regency in 2015

(Source: BPS, 2015)

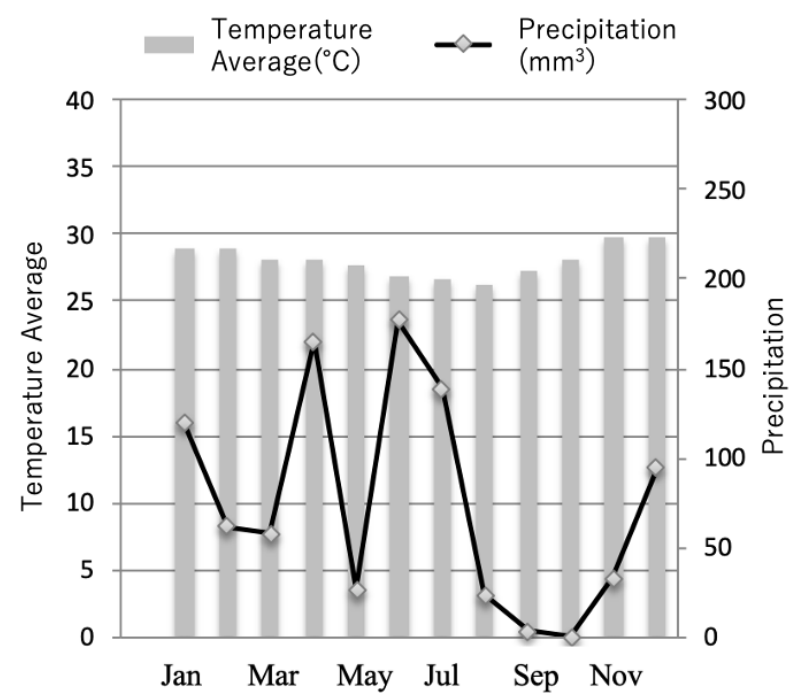

Fig. 1. Hythergraph for Banggai Kepulauan Regency (2015) [16]

Data from three villages, namely, villages A in Bangkulu island, B in Banggai island, and $\mathrm{C}$ in Labobo island, were compared to village $\mathrm{K}$. These villages comprise the settlements of the Sama-Bajau people (Figure 2). Research on villages A and C was conducted on 2019 and on village B from 2016 to 2019.

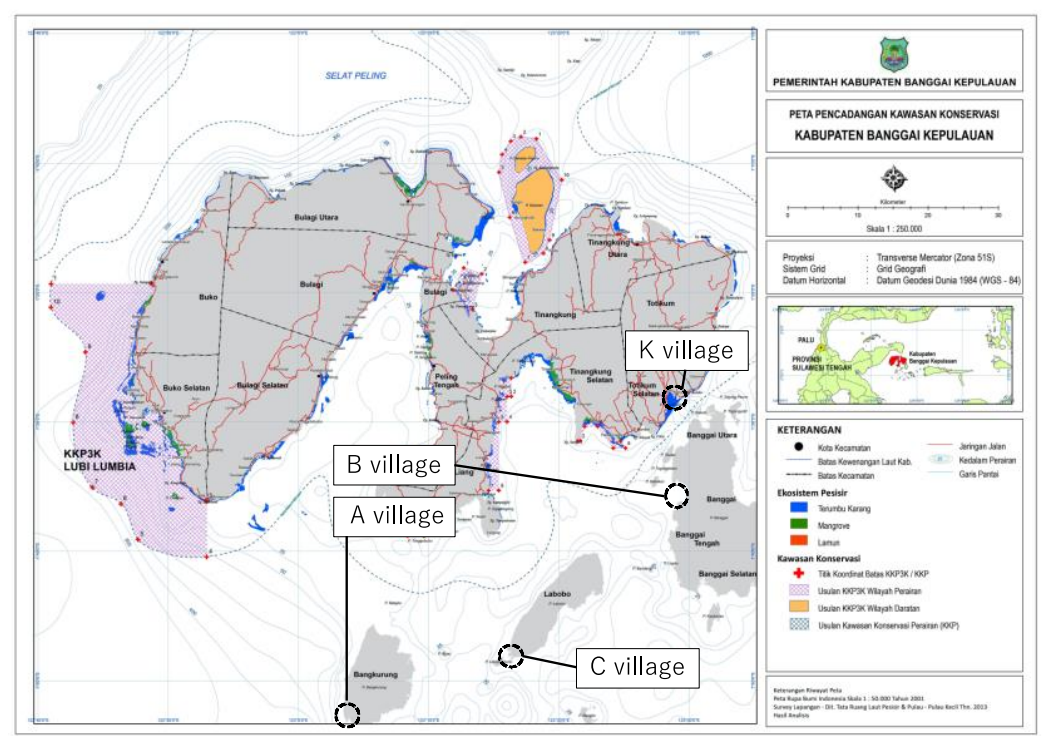

Fig. 2. Research sites in Banggai Islands (Source: [17] with addition from the author for 2020)

According to the interviewees, the four settlements are inseparably linked by family relationships. The main fishing methods in village $\mathrm{K}$ are net fishing, bomb, longline fishing, 
handline fishing, and skin diving. Other sources of livelihood are gathering and cultivation of fish and seaweed (Table 3).

Table 3. Methods of fishing in village K [10]

\begin{tabular}{llccc}
\multicolumn{5}{c}{ Methods of fishing ways in village K } \\
\hline \multicolumn{1}{c}{ Fishing activities } & Local name & Methods & Number of participants & Locations \\
\hline [1] Net fishing & pangaringi & Gill net fishing & $1-4$ & Lana or coastal areas \\
[2] Bomb & panimbaq & Bombing and catching & $2-3$ & Lana etc \\
[3] Longline fishing & panguddoq & $\begin{array}{c}\text { Long-line fishing for general fishes } \\
\text { Long-line fishing for sharks }\end{array}$ & 3 & Lana etc \\
& & Hand-line fishing & $1-2$ & Lana etc \\
[4] Handline fishing & pamissi & Artificial bait fishing for general fishes & 1 & Lana etc \\
& panipo & Artificial bait fishing for octopases & 1 & Lana etc \\
[5] Skin diving & & Spear fishing & $1-2$ & Lana or reef rock \\
& panuung & Spear gun or harpoon & $1-2$ & or reef rock \\
& & Cana or reef rock & \\
\hline Gathering & nubbaq & Catching by instruments & $1-2$ & \\
Cultication of fish & kerambaq & Cultivation at fish preserves & &
\end{tabular}

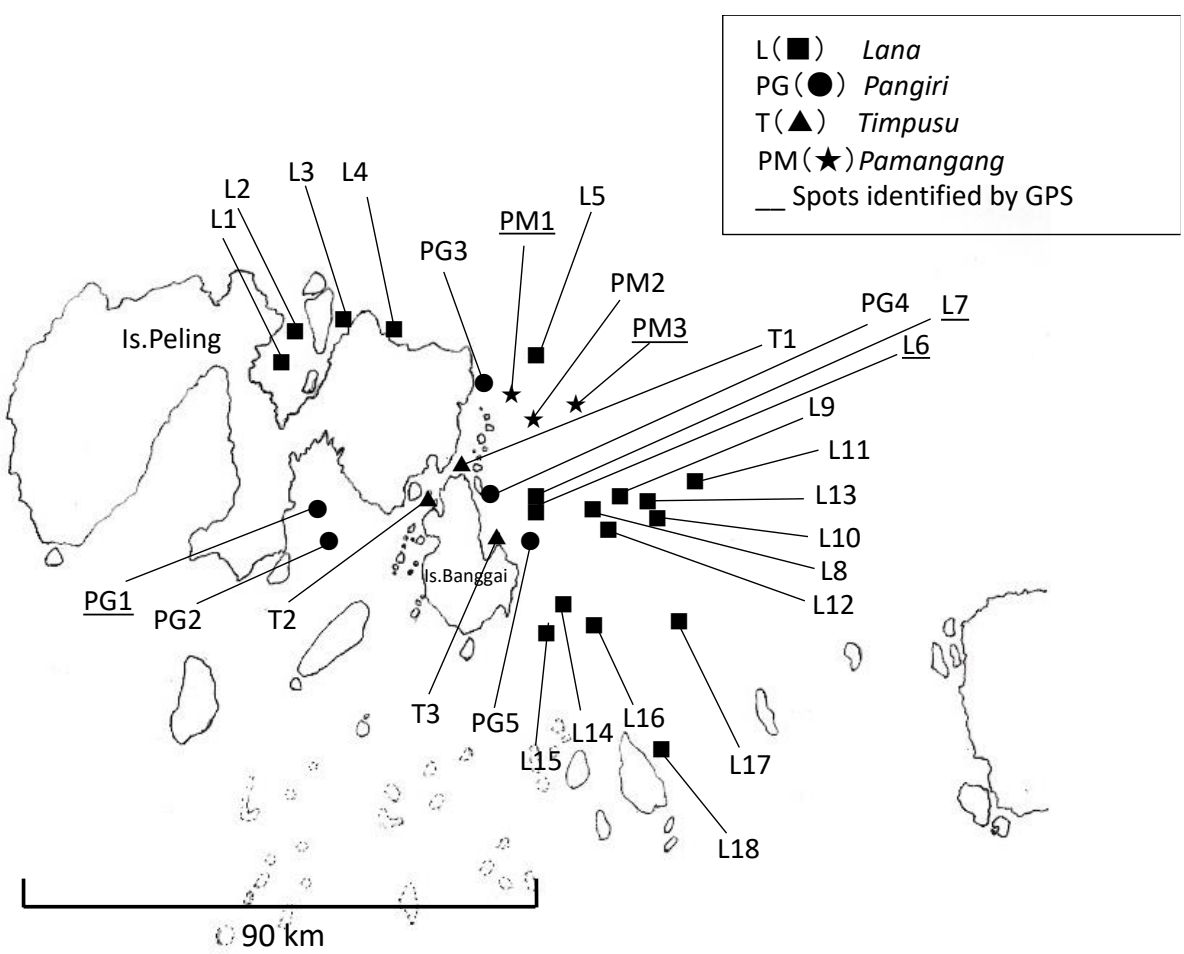

Fig. 3. Location of fishing spots utilized by fishermen in village K [10]

The majority of fishermen in village $\mathrm{K}$ utilize fishing spots in the east side of the village. They classify sea space, including fishing spots, into Lana, Pangiri, Timpusu, and Pamangang [10]. Settlements generally utilize small boat without sails. According to the interviewees from village $\mathrm{K}$, after an era using dwelling boats, they resorted to sailing ships with paddles. The reason for this shift is that sailing ships are easily driven by the direction and strength of the winds, which is a useful characteristic as fishing time and route are 
dependent on winds. However, their fishing style was significantly changed after the introduction of boats with engines because they no longer have to consider the monsoon, although they cannot sail in the direct direction of the monsoon. For example, they cannot sail to the east during the southeast monsoon. Fisherman A and fisherman D was the first people to obtain an engine in village K. They borrowed an engine from a Chinese broker in village K. During this era, fishermen in village K generally sail and fish at the south portion, such as the spots from L15 to L18 in Figure 3. For the first time, however, they sailed to the east and finally found a new fishing spot, namely L11 in Figure 3. The fishing spot name stands for 'a far Lana' and remains the farthest fishing spot to date. In addition, the era indicates that before modernization, livelihood in the village was dependent on seasonal winds. Thus, knowledge about winds was essential for the Sama-Bajau.

Today, the Sama-Bajau people continue to observe seasonal calendars by winds, although they can sail to any place at any given time. During the author's fieldwork, several fishermen were asked about the season for a particular day, and each fisherman answered in reference to the wind calendars. In addition, they are aware when a day is suitable or not for fishing.

\section{Results and discussion}

\subsection{Seasonal classifications in the four settlements of Banggai Islands}

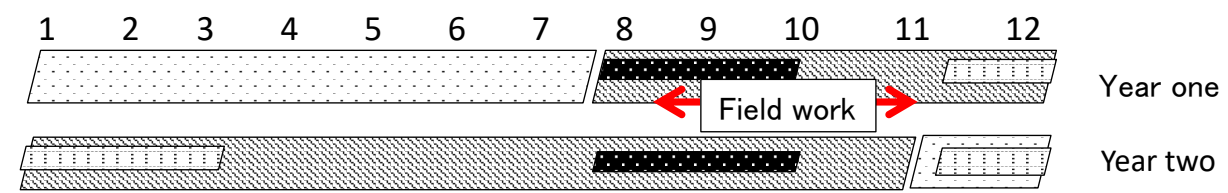

Utara: the season of the north winds. The waves are big in costal areas. It becomes stormy at night; daytime fishing is preferable

Salatan: the season of the south rough winds. The winds become slightly calm during the night; it is stormy during daytime

$\therefore \because \theta \because \theta$ Bangaq : the season of rough winds. It is stormy during daytime; fishing is not advisable

Paneddoh:the season of calm winds. Daytime and nighttime fishing is preferable.

(O) Other wind

Made by presenter

In Salatan season, 4 kinds of wind are mixed; South, West, Southeast, and East.

In these wind, South, West and Southeast wind blow in this order, but the period is not

constant. The East wind blows about 3 times in Salatan season for about a week.

Fig. 4. Classification of winds in village K (Source: Fieldwork by author, 2017-2020)

\subsubsection{Wind calendar for village $K$}

First, as in the case of village $\mathrm{K}$, the interviews revealed that four main seasons are classified according to the direction and strength of the winds, namely, Utara, Salatan, Bangaq, and Paneddoh (Figure 4). Similar to other winds, four wind directions are noted, namely, Selatan, Barat, Tunggara, and Timur, during the Salatan season. The four wind 
directions pertain to the winds of the south, west, eastern south, and east, respectively. In these winds, Selatan, Barat, and Tunggara blow successively in this order. However, their duration is not constant. Timur blows approximately three times during the Salatan season for a duration of approximately one week. Importantly, a cycle of seasons lasts for 2 years, although in general a season can last for 1 year. According to cognition, for example, if 2017 is the first year of a cycle, then June is considered the Utara season for 2017. However, the month of June is considered the Salatan season by 2018. Changes in the seasons are shared among residents in village $\mathrm{K}$, especially among fishermen. The study confirms that the seasonal changes during the fieldwork from 2017 to 2020 have occurred as explained.

Several characteristics were observed in the wind calendar for village $\mathrm{K}$ as follows. During interviews, they did not mention spontaneously to rainy season and dry season. Firstly, the Utara and Salatan seasons are the main seasons, whereas the Banggaq and Paneddoh seasons are more detailed seasons compared with the main seasons. Secondly, the main seasons are dependent on wind direction, whereas the Banggaq and Paneddoh sub-season are dependent on wind strength. Thirdly, the Utara and Salatan seasons occur in irregular patterns, whereas the Banggaq and Peneddoh seasons are nearly regular seasons. And except for a duration of the Salatan season from approximately January to April of the next year, the periods for the main seasons are nearly similar to the scientific calendar.

In their mentions the begin and end of these seasons are off by about a month. They explained that the gap is caused by seasonal transition period, therefore all mentions are same. According to the seasonal classification in village K, the years of 2017 and 2018 are considered the first and second years, respectively. If so, in other words, an odd-numbered year is classified as a first year, whereas the even-numbered year is a second year. The fieldwork in 2017 was conducted from 20th August to 20th October. This period covered the Salatan and Bangaq seasons, during which times, the south winds are blowing. Figure 5 shows the wind direction for the evening of 14th June 2009, which is an odd-numbered year. The illustration shows that the direction of wind is south, which is an opposite direction according to the knowledge of the locals of village K. Figure 6 shows the wind direction for the evening of June 14, 2006, which is an even-numbered year. The figure shows that the direction of wind is south, which is similar to that in 2009 and according to the knowledge of the locals. 


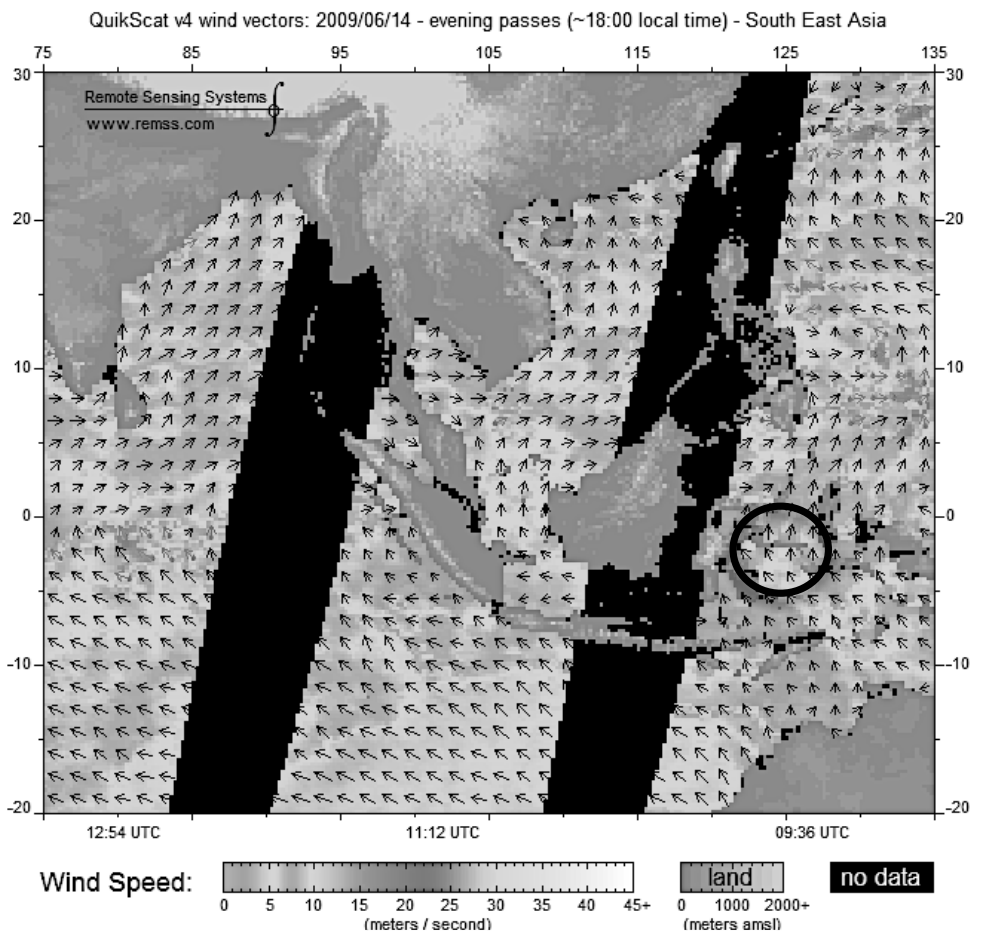

Fig. 5. Wind direction in the evening of June 14, 2009 in Southeast Asia (Source: [18] with addition from the author for 2020)

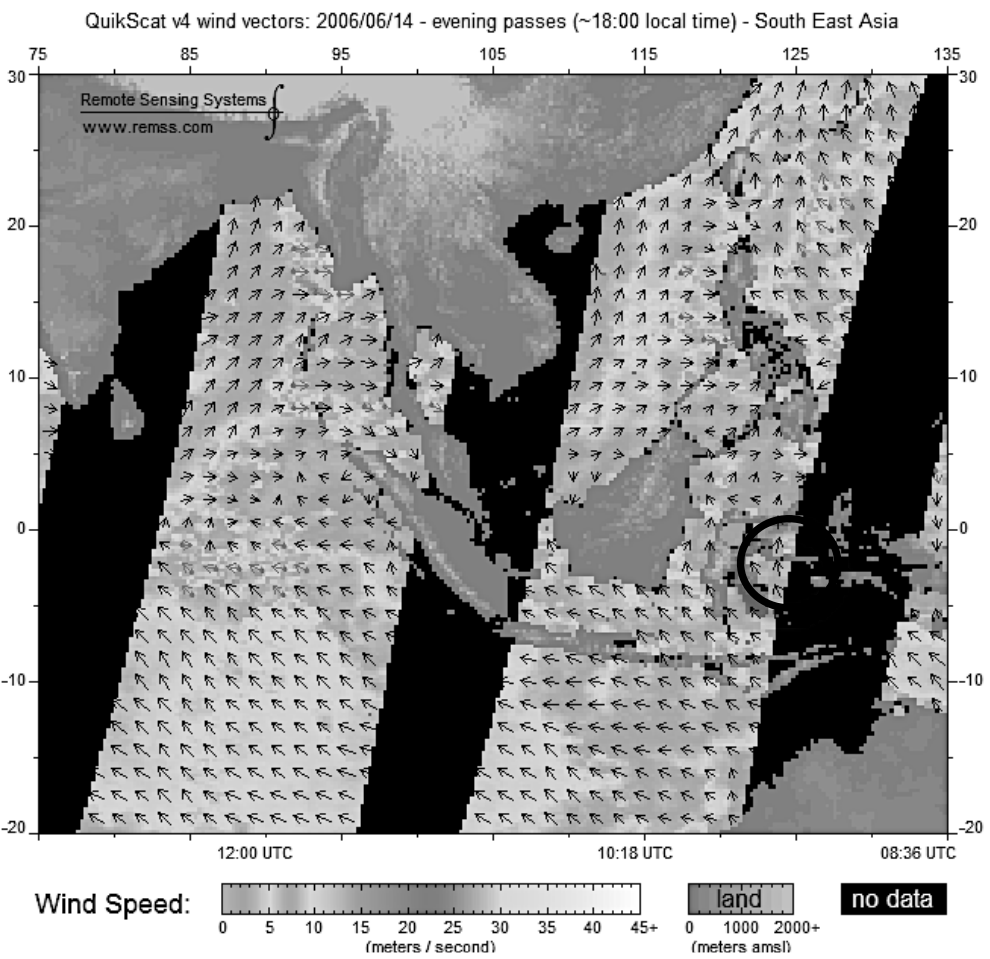


Fig. 6. Wind direction in the evening of June 14, 2006 in Southeast Asia (Source: [18] with addition from the author for 2020)

\section{A Village}

$$
\underline{1}
$$

$4 \quad 5$

6

7

8

9

$10 \quad 11 \quad 12$
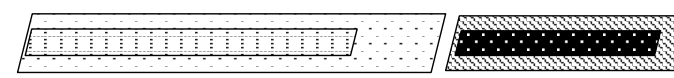

\section{OFour classification by winds}

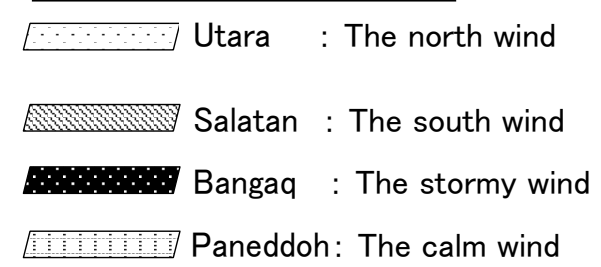

The Salatan and Tunggara winds are prevalent during Salatan season, whereas Barat, Timur, and Utara winds prevail during the Utara season.

Fig. 7. Classification by winds in village A (Source: fieldwork by the author, 2019)

\subsubsection{Wind calendar for village $A$}

As in the case of village A, four main seasons are observed, which are nearly the same with those for village K, namely, Utara, Salatan, Bangaq, and Paneddoh (Figure 7). The cycle of the seasons is completed within 1 year.

The following characteristics are specific to the wind calendar for village A.

Firstly, the Utara and Salatan seasons are the main seasons, whereas the Banggaq and Paneddoh seasons are considered more detailed seasons compared with the main seasons. Secondly, the main seasons (Utara and Salatan) are classified by wind direction, whereas the sub-seasons (Banggaq and Paneddoh) are classified by wind strength. Thirdly, the main and sub-seasons are punctual. 

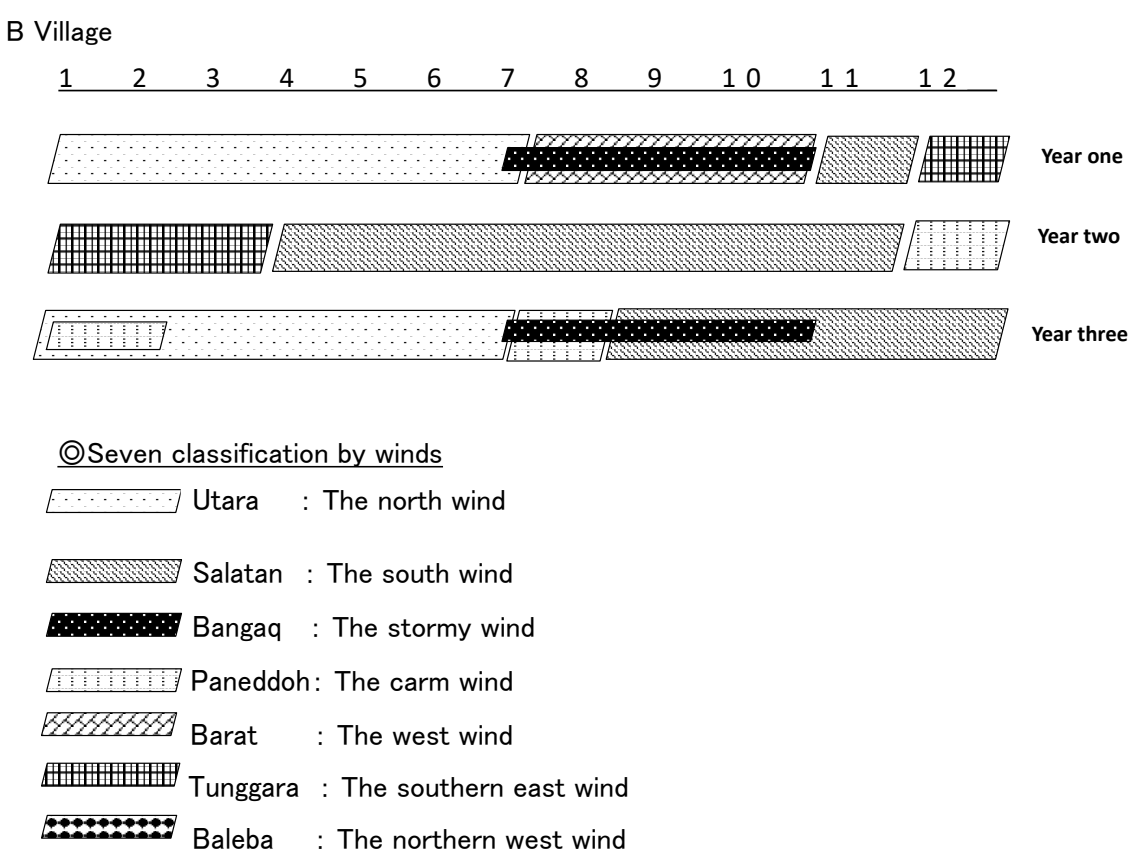

Fig. 8. Classification by winds in B village (Source: Fieldwork by author, 2016-2019)

\subsubsection{Wind calendar for village $B$}

For village B, data indicate seven mains seasons that critically differ from the classification for village K, namely, Utara, Salatan, Bangaq, Paneddoh, Barat, Tunggara, and Baleba (Figure 8). Baleba is wind in the north-west direction. A cycle of seasons lasts for 3 years in contrast to 1 and 2 years for villages $\mathrm{A}$ and $\mathrm{K}$, respectively.

The following characteristics were observed for the wind calendar for village B. Firstly, the Utara, Salatan, Barat, Tunggara, and Baleba seasons are considered the main seasons, whereas the Banggaq season is a more detailed season compared with the main seasons. Secondly, The Paneddoh season is taken as a main and a sub-season. Thirdly, the main seasons are classified by wind direction, whereas the sub-seasons are classified by wind strength. And all seasons are irregular. 


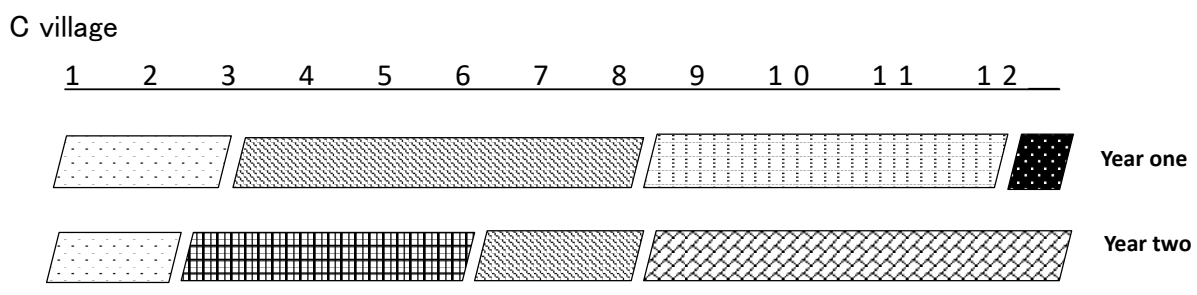

(Q) Six classification by winds

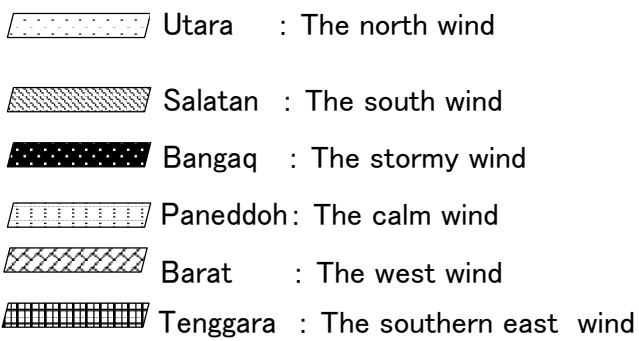

Fig. 9. Classification of winds in village C (Source: fieldwork by author, 2019)

\subsubsection{Wind calendar for village $C$}

Village C features six main seasons, namely, Utara, Salatan, Bangaq, Paneddoh, Barat, and Tunggara (Figure 9). A cycle of seasons lasts for 2 years. In this calendar, however, the six wind classifications are treated individually. In this case, the village differs from the three other villages.

The following characteristics are unique to the wind calendar for village C. Firstly, the seasons are not classified into main and sub-seasons. Secondly, two types of seasons are classified by wind direction or strength. Thirdly, the Utara season is a nearly punctual season. And the Utara season is nearly the same with the scientific calendar. The study presents certain similarities among the villages.

At First, the Sama-Bajau people in the four settlements refer to the north and south winds with importance. Interestingly, each settlement considers the Utara and Salatan seasons as close to the most prominent months of the monsoon. In other words, the villagers observe the occurrence of the northwest and southeast monsoons in Banggai Islands. Secondly, they classify the seasons according to wind direction and strength, which frequently lead to two levels of classification, namely, the main seasons via wind direction and sub-seasons via wind strength.

Thirdly, fishermen from all settlements associate the seasonal calendars with fishing. In other words, their livelihood continues to be influenced by seasonal winds despite modernization.

Despite these similarities, differences in these seasonal calendars are noted. Why then does the seasonal classification for each settlement differ? How they categorize indigenous seasonal calendars?

According to fisherman $\mathrm{D}$ who had immigrated to village $\mathrm{K}$, 'If (someone) has the experience of staying in a settlement, (he) can understand the season of that settlement. If not, (he) cannot know it.' In addition, the fisherman stated that 'When (we) utilize only the 
natural calendar (kalender alam in Indonesian), no one will mistakenly identify a season. However, after the modern calendar (I do not know who made it, maybe a wise one), people started making mistakes. Therefore, using a natural calendar is better for identifying the seasons' (recorded by the author in 2020). Another fisherman in another settlement in Banggai regency said that 'The fishing season of a certain species of fish is known by the blooming season of a certain flower. The fishing season for another species is indicated by a transitional period of a certain wind' (recorded by the author in 2020). In fact, except for the wind calendar, sometimes fishermen explain the seasons in village K. For example, they utilize some celestial bodies for identifying seasons whereas it used for identifying location when they sail. Table 4 shows a list of useful celestial bodies that are useful for identifying a season in village $\mathrm{K}$.

Table 4. Useful celestial bodies used for identifying seasons in village K (Source: fieldwork by author, 2016-2017)

\begin{tabular}{cccc} 
Local name & Meanings & English name & Scientfic name (IAU) \\
\hline Mmau timur & Star of the east & Unknown & Orionis \\
Mmau barat & Star of the west & Unknown & Unknown \\
Mmau utara & Star of the north & Unknown & Unknown \\
Mmau salatan & Star of the south & Unknown & Unknown \\
Mmau layah (1) & Star of a sail & Unknown & Volans Etc \\
Mmau layah (2) & Star of a sail & Unknown & Unknown \\
Mmau pitu (Pupuru) & Seven stars (Gathering stars) & Pleiades & Pleiades \\
Tanda tellu & Landmark of three & Orion's Belt & J,,$\zeta$ Orionis \\
Niyor (present one) & Unknown & Aldebaran & $\alpha$ Tauri \\
Niyor (previous one) & Unknown & Sirius & Sirius Canis Major \\
Mmau llau & Star of the noon & Venus & Venus \\
Mmau Naga & Star of Naga (legendary dragon) & Milky Way Galaxy & Milky Way Galaxy \\
Mmau tunggara & Star of southeast & Canopus & $\alpha$ Carinae \\
Mmau baleba & Unknown & Unknown & Unknown
\end{tabular}

Fishermen in village $\mathrm{K}$ utilize celestial bodies for two reasons, namely, landmark for sailing and landmark for seasons. They carefully observe celestial bodies that appear during specific times and seasons. They also note if a certain star has appeared in a certain direction and at a certain time, then a certain season is beginning. In general, the settlements of the Sama-Bajau people are found on the coastal areas, such that they can easily see the sky without obstruction. However, the study estimates that they do not note the correct time of the appearance of celestial bodies or observe it from an individual perspective and interpretation, such as 'when I pray before sleeping.'

\subsection{Seasonal calendar of the Sama-Bajau people in coral reef areas}

Previous studies on the Sama-Bajau people typically focused on communities found in coral reef areas.

\subsubsection{The Sama-Bajau people in Semporna county, east coast of the Sabah state, Borneo island}




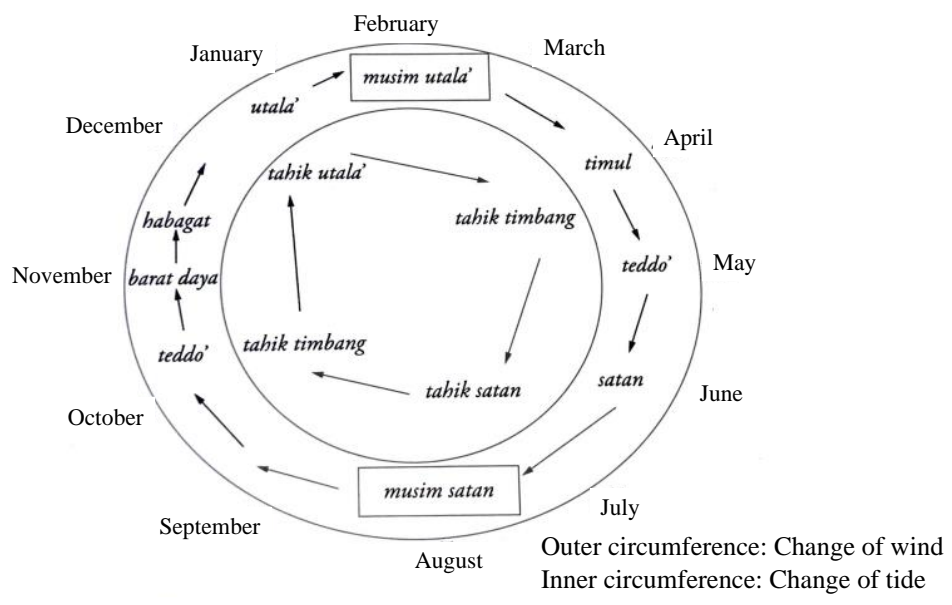

Fig. 10. Concept of seasonal classification by the Sama-Bajau people in Sabah state, Borneo island (Source: [12], translated by the author)

In the remote islands of Semporna, the southwest monsoon appears from approximately May to September, whereas the northeast monsoon is prevalent during December to March. The Sama-Bajau people in this area call the southwest monsoon as musim satan or 'season of the south' and the northeast monsoon as musim utala or the 'season of the north.' Within the two seasons, they people further classify them according to wind direction and strength. However, these detailed classifications are relatively dependent on the day and can thus be flexible. Importantly, they also recognize the cycle of tides in a year. Such a classification is recognized together with the wind classification. For example, a period of tahik utala' pertains to the 'tide of the north,' which nearly overlaps with musim utala', such that the name uses utala' or north. Rintaro mentioned that 'The fishing activity of the Sama-Bajau people have been conducted traditionally with the constraints of the seasonality of the wind, moon phase, and tidal movement. This tendency is indirectly proven by the fact that they classify in detail and recognize the seasons, moon phases, and tidal situation by the direction and strength of winds' [12].

In this case, the important point is that the Sama-Bajau people in Semporna islands or the coral reef areas recognize the seasons by wind direction and strength, the wind seasons together with the moon phase and tidal movement, and the seasonal classification is punctual.

The point that the seasons were recognized by wind direction and strength is common between the settlements in Banggai and Semporna islands. However, these settlements differ in second point that the wind seasons is recognized together with the moon phase and tidal movement. Because the Sama-Bajau people do not recognize the connection between the wind calendar and tidal moon calendar, although they use an indigenous calendar based on the moon phase.

\subsection{Irregular calendar}

Previous studies have been conducted on irregular calendars. 


\subsubsection{Dourou society in North Cameroon}

A year is divided into 12 siin (months). However, siin does not use the concept of dates and nor the period of a siin. The Dourou society is aware only of the siin, but not the exact day. Nevertheless, Dourou swidden farmers engage in their livelihood by referring to a seasonal calendar based on siin. Previous studies reported that these farmers identified the seasons making a connection with the slash and burn cycle in bush areas. Therefore, their concept of time is deeply involved with the annual composition of the farmers' pattern (i.e., bush, slash, and burn) [4]. Although the relationship between environmental cues remains unclear, the study emphasizes that 'in correspondence with agricultural calendar and Western calendar, inevitably there will be a time deviation' [4].

\subsubsection{The Sundanese village in West Java, Indonesia}

In the upland fields in the Sundanese hamlet in Priangan, the timing of upland agricultural operations is not fixed according to a calendar, but reckoned by continuous and careful observation of indicators, such as seasonal fluctuations in rainfall frequency, moisture and wind direction, and phenological changes in wild flora. The seasonal appearance or specific behavior of certain insects and birds are marked by stellar events, such as the heliacal rising and culmination of the Pleiades, Orion's belt, and the Southern Cross. The peasants' reckoning of the timing of agricultural operations reflects the persistence of the traditional Javanese agricultural calendar [5].

The current study suggests that peasants largely refer to natural indicators to estimate the appropriate time for agriculture. The two cases suggest that in local societies, farmers carefully but vaguely reckon and observe certain natural indicators. Importantly, these calendars are deeply connected with certain forms of livelihood, such as agriculture and fishing.

\section{Conclusion}

The study draws its conclusions from the abovementioned cases and comparisons. First, the Sama-Bajau people have adopted seasonal calendars according to the different ecological and environmental conditions of each settlement. Second, the irregular seasonal calendar is recognized to be related to the livelihood of the people.

The study finds that the Sama-Bajau people mainly refer to information from their ecological environment, such as the moon phase, tidal movement, blooming of flowers, fish movement, and wind. They flexibly select more appropriate one from a withdrawal of ecological information to know the area. As a result, they consider calendar appropriate based on a combination of wind and tidal movements for fishing in coral reef areas. Furthermore, fishermen from Banggai Islands who often sail the outer seas utilize a calendar based on a detailed information of winds. However, differences in the wind calendars of the four settlements in Banggai Islands are observed. Thus, the question arises: Why do they use different wind calendars even if the settlements are in same area and sail to the outer sea? This point connects to the second conclusion.

The study infers that the Sama-Bajau people organize the seasonal calendar in relation to their livelihood cycle. The cases of the Dourou and Sundanese farmers suggest that they devised irregular calendars to understand the seasons relative to their agricultural activities. In the same manner, people who live within a certain environment share common characteristics that are recognized as part of the seasonal calendar in connection with their livelihood. The study points out the possibility that the cognition of the Sama-Bajau people 
in this respect is similar. Fishing is widely known as the main livelihood of the Sama-Bajau people; however, they also utilize agricultural resources, such as vegetables and fruits during seasons of strong winds, where fishing is not feasible. Furthermore, the study suggests the possibility that the second livelihood or "minor-subsistence' (Matsui, 1998) influences the recognition of the concept of the seasons.

The paper presented seasonal classification dependent on winds, which is applied by fishermen in the Banggai Islands. To the best of our knowledge, the study is the first to emphasize the characteristics of the Sama-Bajau people who mainly fish for a living in the outer sea. By analyzing and comparing the different seasonal calendars used by SamaBajau across settlements, the study highlights the organization of their calendars. Previous studies mainly focused on the relationship between seasonality and agricultural operations of indigenous people. In contrast, the present study highlights the various concepts of seasonality as perceived by the fishermen. The results are meaningful for future research on the relationship between ecological environments and people.

\section{Acknowledgements}

This research was supported by the Ministry of Research, Technology, and Higher Education of the Republic of Indonesia, Institute for the Culture of Travel (Japan); scholarships from the Japan Student Services Organization; supporting program for Interaction-based Initiative Team Studies (PI: Takuro Furusawa); scholarships for study abroad from the Heiwa Nakajima Foundation; and the Japan Society for the Promotion of Science (KAKENHI), grant number 19J14629.

\section{References}

1. Aoyama W., (青山, 和佳), 貧困の民族誌: フィリピン・ダバオ市のサマの生活. Tokyo: Tokyo University Press (2006)

2. Furusawa T., (古澤, 拓郎), Indigenous calendar system in western Sumba island, Indonesia: Analyses of inter-area signal transmissions for the month of bitterness and the month of sea worms (インドネシア・スンバ島西部の在来暦法一「苦い月」 と「ゴカイ月」をめぐる地域間シグナル伝達の分析から一), Asian and African Area Studies, 17(1), 1-38 (2017)

3. Grimes B., \& F., Ethnologue: Language of the world (15th ed.). Dallas: Summer Institute of Linguistics (2000)

4. Hata N. (端, 信行), The native concept of seasonal cycle (months) and agricultural calendar of the Dourou Society in North Cameroon [ドゥル族の季節観と農作業暦]. Bulletin of the National Museum of Ethnology (国立民族学博物館研究報告), 1(3), 537-564 (1976)

5. Igarashi T.(五十嵐, 忠孝), Agricultural operations, seasonality, and stars: Annual cycle of upland cultivation in a Sundanese Village, West Java (農作業, 季節, 星一 西ジャワ・プリアンガン高知における畑地耕作をめぐる季節性と農作業のタ イミングー) Tōnan Ajia Kenkyū, 25(1), 85-108 (1987)

6. Matsui T.(松井, 健), マイナー・サブシステンスの世界一民俗世界における労 働・自然 - 身体, In Toru. Shinohara (篠原, 徹) (Eds.), 現代民俗学の視点 1 民族の 技術, 247-268, Asakura Publishing Co. Ltd (1998)

7. Nagatsu K. (長津, 一史), フィリピン・サマの漁撈活動の実態と環境観一民俗 環境論的視点から一, 京都大学人間 - 環境学研究科文化 - 地域環境学専攻修士 
学位申請論文 (1995)

8. _-______________ Coral reef fisherfolks and their space Cogrnition:

Notions of "land," "sea," and coral reef space among Sama in Sitangkai, Sulu archipelago (海の民サマ人の生活と空間認識ーサンゴ礁空間 $\mathrm{t}$ ’bbaの位置づけを 中心にしてー). Tōnan Ajia Kenkyū, 35(2), 261-299 (1997)

9. ————————————, 異種混淆性のジェネオロジー: スラウェシ周辺 海域のサマ人の生成過程とその文脈, 民族大国インドネシア: 文化継承とアイ デンティティ. 249-284. 木犀社 (2012)

10. Nakano M. (中野, 真備), Outer sea fishing and spatial cognition of the Sama-Bajau people in the Banggai Islands, Indonesia (インドネシア・バンガイ諸島のサマ人 の外洋漁撈と空間認識). Asian and African Area Studies, 19(2), 184-206 (2020)

11. Nimmo H. A., Reflections on Bajau history, Philippine Studies, 16(4), 32-59 (1968)

12. Ono R.(小野, 林太郎), 海域世界の地域研究一海民と漁撈の民族考古学一. Kyoto: Kyoto University Press (2011)

13. Pallesen K., Culture contact and language convergence, Linguistic Society of The Philippines, Monograph Series (24), Manila, Linguistic Society of the Philippines (1985)

14. Sopher D., \& E., The sea nomads: A study of the maritime boat people of Southeast Asia. (reprinted in 1977 with postscript), Singapore: National Museum of Singapore (1977 (1965))

15. Tony J., Whitten G., Henderson, S., \& M. Mustafa, The ecology of Sulawesi, the ecology of Indonesia series, Volume 4. Hong Kong: Periplus Editions (2012)

16. Badan Pusat Statistik $<\underline{\text { https://bangkepkab.bps.go.id }>}\left(18^{\text {th }}\right.$, September 2020)

17. Kebupaten Banggai Kepulauan. Peta pencadangan Kawasan koservasi kebupaten Banggai kepulauan for 2013.

18. QuickSCAT https://winds.jpl.nasa.gov/missions/quikscat/ $\left(18^{\text {th }}\right.$, September 2020) 